\title{
Definition of Leadership in Africa within the Twenty-first Century Context: Empirical Research on Leadership in Africa
}

\section{Matete Lerutla Renier Steyn}

\begin{abstract}
Orientation: Leadership is a widely used construct and there are numerous articles across multiple disciplines. In the past few years there has been growing interest to investigate the construct of leadership in Africa. Much of what is written is conceptual, and empirical articles on African leadership remain sparse. Research purpose: This paper reports on the findings of the systematic literature review that was conducted on leadership in Africa. The paper presents a qualitative review of empirical research highlighting key findings and implications for future research. Research method: The research investigation followed the traditional body of knowledge framework of concepts, statements, definitions, and conceptual frameworks to systemize reports on leadership in Africa. Articles were identified, selected and analysed using the systematic literature review methodology. Articles, statements, definitions, models, typologies, theories, and paradigms were explored and interrogated in each article to understand how they are linked to leadership in Africa. Main findings: A total of 96 articles were retrieved from eight electronic search engines. Following the application of inclusion and exclusion criteria, only thirteen articles met the set criteria - suggesting that little empirical research is conducted on leadership. The findings illustrated the extent of paucity of empirical research on leadership in Africa and clearly indicate a definite need to investigate it, and then to build on the understanding of African leadership through empirical research. The published articles showed that the concept of African leadership is seldom defined, measure-
\end{abstract}


ments are typical of the Western tradition, and that the set hypotheses do not include the African context. Furthermore, no Africa-specific models or theories are presented. The positivist paradigm was most often used in the research. Practical implications: The literature review has provided an understanding of the extent of the lack of empirical work around leadership in Africa. There is a definite need for systematic empirical work to explore what leadership means in Africa, and to build the concept of African leadership as a concrete scientific construct. The paper concludes by providing suggestions on how to bridge the gap towards understanding leadership in Africa.

Keywords: Leader, Leadership Practice, Africa, Conceptual Framework, Body of Knowledge

\section{Introduction}

Leadership is a concept that is known and referred to in organizations and societies as a construct associated with, or believed to be a key to organizational effectiveness or societal success (Garg \& Ramjee 2013:1430). It alludes to improved business operations and performance (Mokgolo, Mokgolo \& Modiba 2012:2; Thom 2014:32), and how people respond to change (Nkomo \& Kriek 2011:453). The construct of leadership has received much global attention by researchers and scholars across different disciplines (Marturano \& Gosling 2008:xxiii). Furthermore, Dinh et al. , (2014:36) state that over the last two decades, leadership theories have been advanced exponentially. Yet, despite the recognition and the 'alleged' importance of leadership, and amidst the increasing growth in leadership research, there is no universal understanding of what leadership is (Bolden \& Kirk 2009:60). Similarly, Grint (2005:1478) argues that leadership remains an elusive and contested concept, and it is highly unlikely that an agreement on what it entails, could emerge.

Western leadership paradigms, which have dominated research on the topic of leadership, are being questioned (Bolden \& Kirk 2009:69). There is a growing theoretical movement which suggests that leadership should be looked at within the context in which it is practiced (Humphreys et al. 2010:118; Littrell \& Nkomo 2005:563; Mbigi 2000:24; Posner 2012:573; Van 
der Colff 2003:258). Researchers argue along these lines that leadership practices always occur within a specific context (Mboup 2008:95; Haruna 2009:941; Jones et al. 2012:68; Muchiri 2011:440). To this end, it is observed that some research evolved from exploring individual leadership attributes to researching interactions and processes that form leadership practice (Avolio, Walumbwa \& Weber 2009:422), thus focussing more on context.

The geographical context is one that has received much research attention in Africa. It has been observed that while global leadership practices of the eighteenth to twentieth centuries were influenced by Eurocentric theories, researchers are beginning to realize that the African context has its own values and practices that should be an integral part of leadership in Africa (for example; Bolden \& Kirk 2005:5; Littrell \& Nkomo 2005:563; Chatbury, Beaty \& Kriek 2011:157). With this shift, there has been interest in how culture influences leadership practice in Africa (Littrell \& Nkomo 2005:562; Mbigi 2000:21; Van der Colff 2003:258). Despite the interest, it was discovered that very little empirical research has been conducted to address leadership on the African continent (Walumbwa, Avolio \& Aryee 2011:432). Kuada (2010:9) reiterates this and states that while a good deal has been written on the subject of leadership in Africa, there is still a shortage of academic, and particularly empirical, publications on the subject.

In a quest to contribute to the academic body of knowledge about leadership within the African context, this study presents an exploration of empirical endeavours on the subject. Literature was systematically reviewed to identify all research conducted in the last seven years where the construct of leadership in the African context was investigated. The reason for conducting a systematic literature review was to ensure that a thorough and unbiased method was used to identify, select and report on the available literature under investigation (Nightingale 2009:381; White \& Schmidt 2005:54). Through the literature review process, the researchers' objective was to present and critically evaluate the standing of the current body of knowledge as it pertains to a uniquely African leadership.

\section{Literature Review}

This study is a systematic literature review of empirical research on leadership in Africa. A summary of the body of knowledge is the outcome of this study, 
and will be presented under the heading 'Findings'. These findings would traditionally be presented as the literature review. In the section that follows below, however, the focus will be on the important matter of literature reviews and specifically the uniqueness of systematic literature reviews.

A literature review is central to the argument of all academic texts as it allows researchers to present a broad perspective on the topic under investigation (Green, Johnson \& Adams 2006:102). Robson (2011:51) states that literature is that which is already known and written down according to one's research construct or theme. Furthermore, a review of the literature is important as it helps not only with the design of the research project, but also with deciding on the questions that should be investigated during the research project.

During this particular research process, the researcher used a systematic review of the literature, as opposed to using the conventional or traditional method of reviewing literature. Traditional literature reviews involve the process of identifying, locating and analysing the relevant documents regarding the topic under investigation (Robson 2011:51). The documents that are used under traditional literature review broadly include articles, abstracts, reviews, monographs, dissertations, books, and any research publication (Gay \& Airasian 2003:16). Nightingale (2009:381) states that the concept of systematic review will minimize researchers' bias on selecting and extracting empirical data. A systematic literature review is described as a quantitative process that helps to integrate empirical data by providing a summary and critique of the data (Green et al. 2006:106; White \& Schmidt 2005:381). It is an approach that objectively reports on the current body of knowledge of a particular research topic, based on published articles (Robson et al. 2007:342; White \& Schmidt 2005:54). This approach to reviewing literature emphasizes the relevance and comprehensiveness of the material as well as the quality of the evidence reviewed (Robson 2011:52). It has provided meaning in the context of evidence-based approaches and the synthesis of research findings (Tranfield, Denyer and Smart 2003:208; Robson 2011:103). The approach is an essential step in any pragmatic research process as it enables the researchers to identify popular, dominant or evolving issues, themes or topics, and to determine diversity of research findings (Robson 2011:103).

Nightingale (2009:381) argues that the systematic literature review methodology creates a reliable base of data accumulated from a range of 
studies. Nightingale also provides the following guidelines for the methodology that should be applied when conducting a systematic literature review:

- The systematic literature review should clearly state the aims and objectives of the review;

- It should indicate the criteria for inclusion and exclusion of studies;

- It should indicate how the studies will be identified; and

- The manner in which the findings will be analysed.

Nightingale's (2009:381) aforementioned structure does not differ fundamentally from the way in which White and Schmidt (2005:293) present the systematic literature reviews. The Nightingale (2009:381) strategy will be followed to investigate leadership in Africa and to systemize knowledge in this field. This study goes further than Nightingale (2009:381), and White and Schmidt (2005:293) by specifying beforehand how the discovered literature will be analysed. The body of knowledge framework of De Vos et al. (2011:180) was used. As stated in the opening sentence of this section, this literature review section has not presented literature on leadership in Africa, but rather literature on literature reviews. Literature on leadership in Africa is presented as 'Findings'.

\section{Problem Investigated}

As illustrated in the introduction section, there is a growing interest in studying leadership within the context it is practiced, and Africa in particular has been one geographic context of interest. In addition, reference to 'African leadership' or 'leadership in Africa', suggests that within the African social context, the constructs of leadership or leadership practice are defined differently from the rest of the world.

However, research on leadership specifically pertaining to Africa, has not been systemized, therefore hampering the understanding of the phenomenon, and leaving a vacuum in which potential researchers need to operate. This article attempts to fill this void by investigating the extent of the empirical work that has been conducted in Africa on leadership by using Nightingale's (2009) approach for conducting the review (described above), 
and the guidelines provided by De Vos et al. (2011:181) for structuring the content of the review (discussed below).

\section{Research Objectives}

The objectives of this research were the following:

- To locate a comprehensive collection of empirical articles on leadership in Africa;

- To structure the available literature according to a standardized scheme of organizing knowledge;

- To critically analyse how the available information corresponds to the standard scheme of a body of knowledge; and

- To make recommendations on future research that will contribute to establishing a comprehensive body of knowledge on leadership in Africa.

\section{Research Method}

The research method used in this study is linked to the purpose of this document, which is to provide a systematic and qualitative review of empirical research conducted on the topic of leadership in the African context. This section describes the process that was followed to assess and analyse contemporary academic publications on leadership in Africa.

\section{Sampling}

The sample used during any research process must be representative enough to allow for conclusions and generalizations (Creswell 1998:65). The search for relevant information was extensive, including many databases and specific material excluding irrelevant information. The main aim was to trace as many as possible published empirical articles on leadership in Africa. Green et al. (2006) state that at least two databases should be searched to provide for reasonable breadth and depth on the topic. To this end, two broad databases (EBSCOhost and ProQuest) were used to search for articles. 
Numerous measures were established in order to be specific. The first was the use of keywords; *leader (leadership) and Africa* (African), and these keywords had to appear in the title of the article. Method* (methodology) was used as a keyword to appear anywhere in the text, as empirical articles usually have such a section. Babbie and Mouton (2001:192) indicate that when building the body of knowledge, only articles accepted in scientific research should be included. Green et al. (2006:105) also state that when searching for empirical literature only reputable publication journals will give credible and current information on a subject under investigation. Therefore, only articles that where reviewed, and peer-reviewed scholarly journal articles were included in the final selection. In order to ensure currency, only articles published over the past seven years (2007-2014) were incorporated. For practical reasons, the search was limited to an electronic search of articles published in English. The search was conducted over a period of six months, from March to August 2014.

In order to assess relevance (Kable \& Maslin-Prothero 2012:89) the abstracts of the found articles were first read to assure the appropriateness of the article to the search criteria. The articles had to have a methodology section to suggest that they were created through empirical findings. Articles that were not published in English were excluded. In the process we decided to disregard single page articles, conference abstracts, newspaper articles, and articles that referred to leadership superficially or peripherally. In addition, articles that focused on 'African-American' leadership were excluded. Those that complied with the inclusion criteria were documented and removed duplicates were retrieved.

\section{Data Analysis}

The articles were analysed using the three building blocks of science as established by De Vos et al. (2011:46), i.e. to determine: which concepts were commonly investigated in empirical studies; often-used statements (definetions, hypotheses, propositions, and truth statements); and the conceptual frameworks (typologies, models, theories, and paradigms), applied during empirical work. Below is a summary of how the different building blocks were identified.

Concepts were distinguished as keywords that appeared on the keyword list of selected articles and they provided an all-encompassing view 
of the subject that the article is addressing. Only concepts that were reported in the articles were stated in the findings.

Statements include definitions, hypotheses, propositions, and truth statements. Definitions were identified by sentences that included the words 'definition', 'described as', 'defining', and 'viewed as'. Hypotheses and propositions were categorized and identified in the articles as statements of expected outcomes that the researcher aimed to prove, while truth statements were identified as statements that were formulated from testable claims.

Conceptual frameworks refer to typologies, models, theories, and paradigms used in the various articles. References to groupings of concepts with the same characteristics were seen as typology, references to scientific and hypothetical frameworks used to explain concepts were recorded as models, and proven frameworks - explaining underlying forces - were linked to theories.

The qualitative method of analysis used above is similar to that which Babbie and Mouton (2001:270) outlined.

\section{Findings}

During the literature review process two reputable electronic search engines, EBSCOhost and ProQuest, were used to conduct the systematic literature review. Eight databases on EBSCOhost (Africa-Wide Information, Business Source Complete, ERIC, Humanities Source, Academic Search Premier, PsychARTICLES, PsycCRITIQUES, and PsycINFO) were searched and 51 articles were retrieved that matched the selected keywords as described above. Seven databases were searched with the ProQuest search engine, (applied social sciences index and abstracts (1987-current); COS Scholar Universe information; ebrary ${ }^{\circledR}$ ebooks information; ERIC (1996-current); Library and Information Science Abstracts (1969-current); ProQuest Business Collection (1951-current); and ProQuest Central (1971-current) and 45 articles were retrieved. A total of 96 articles were found on all databases. Following the inclusion and exclusion criteria, only thirteen articles, as presented in the table below, were deemed relevant in terms of meeting the search criteria and the relevance to the study. Based on the outcome of the findings, it is evident that while a lot is written about leadership, there have only been a few empirical studies on the subject, especially in the African context, over the past seven years. 


\begin{tabular}{|c|c|c|c|c|c|c|}
\hline \# & Author & Year & $\begin{array}{l}\text { Research } \\
\text { topic }\end{array}$ & Journal & $\begin{array}{l}\text { Author's } \\
\text { Affiliation }\end{array}$ & $\begin{array}{l}\text { Research } \\
\text { Method }\end{array}$ \\
\hline 1 & $\begin{array}{l}\text { Banatu- } \\
\text { Gomez, } \\
\text { M.B. \& } \\
\text { W.G. } \\
\text { Rohrer }\end{array}$ & 2011 & $\begin{array}{l}\text { The } \\
\text { influence } \\
\text { of } \\
\text { leadership } \\
\text { practice } \\
\text { 'Inspiring } \\
\text { a Shared } \\
\text { Vision' on } \\
\text { group } \\
\text { norms in } \\
\text { the } \\
\text { organiza- } \\
\text { tional } \\
\text { culture of } \\
\text { financial } \\
\text { institutions } \\
\text { in Gambia, } \\
\text { West } \\
\text { Africa. }\end{array}$ & $\begin{array}{l}\text { Journal of } \\
\text { the } \\
\text { American } \\
\text { Academy of } \\
\text { Business }\end{array}$ & $\begin{array}{l}\text { Rowan } \\
\text { University } \\
\text { (USA) }\end{array}$ & Quant. \\
\hline 2 & $\begin{array}{l}\text { Bolden, } \\
\text { R. \& P. } \\
\text { Kirk }\end{array}$ & 2009 & $\begin{array}{l}\text { African } \\
\text { leadership: } \\
\text { surfacing } \\
\text { new } \\
\text { under- } \\
\text { standings } \\
\text { through } \\
\text { leadership } \\
\text { develop- } \\
\text { ment. }\end{array}$ & $\begin{array}{l}\text { International } \\
\text { Journal of } \\
\text { Cross } \\
\text { Cultural } \\
\text { Manage- } \\
\text { ment }\end{array}$ & $\begin{array}{l}\text { University } \\
\text { of Exeter } \\
\text { (UK); } \\
\text { University } \\
\text { of the West } \\
\text { of England } \\
\text { (UK) }\end{array}$ & Qual. \\
\hline
\end{tabular}




\begin{tabular}{|c|c|c|c|c|c|c|}
\hline 3 & $\begin{array}{l}\text { Bush, T. } \\
\text { \& D. } \\
\text { Glover }\end{array}$ & 2013 & $\begin{array}{l}\text { School } \\
\text { manage- } \\
\text { ment teams } \\
\text { in South } \\
\text { Africa: a } \\
\text { survey of } \\
\text { school } \\
\text { leaders in } \\
\text { Mpuma- } \\
\text { langa } \\
\text { Province. }\end{array}$ & ISEA & $\begin{array}{l}\text { University of } \\
\text { Nottingham } \\
\text { (UK) }\end{array}$ & Quant. \\
\hline 4 & $\begin{array}{l}\text { Chatburry } \\
\text { A., D. } \\
\text { Beatty \& } \\
\text { H.S. } \\
\text { Kriek }\end{array}$ & 2011 & $\begin{array}{l}\text { Servant } \\
\text { leadership, } \\
\text { trust and } \\
\text { implicat- } \\
\text { ions for the } \\
\text { 'base-of- } \\
\text { the- } \\
\text { pyramid' } \\
\text { segment in } \\
\text { South } \\
\text { Africa. }\end{array}$ & $\begin{array}{l}\text { South } \\
\text { African } \\
\text { Journal of } \\
\text { Business } \\
\text { Manage- } \\
\text { ment }\end{array}$ & $\begin{array}{l}\text { University of } \\
\text { Pretoria } \\
\text { (RSA); } \\
\text { University of } \\
\text { the Witwaters- } \\
\text { rand (RSA) }\end{array}$ & Quant. \\
\hline 5 & $\begin{array}{l}\text { El Ansari, } \\
\text { W. }\end{array}$ & 2012 & $\begin{array}{l}\text { Leadership } \\
\text { in } \\
\text { community } \\
\text { partner- } \\
\text { ships: } \\
\text { South } \\
\text { African } \\
\text { study and } \\
\text { experience. }\end{array}$ & $\begin{array}{l}\text { European } \\
\text { Journal of } \\
\text { Public } \\
\text { Health }\end{array}$ & $\begin{array}{l}\text { University of } \\
\text { Gloucester- } \\
\text { shire (UK) }\end{array}$ & Quant \\
\hline
\end{tabular}




\begin{tabular}{|c|c|c|c|c|c|c|}
\hline 6 & $\begin{array}{l}\text { Garg, } \\
\text { A.K. \& } \\
\text { T. } \\
\text { Ramjee }\end{array}$ & 2013 & $\begin{array}{l}\text { The } \\
\text { relationship } \\
\text { between } \\
\text { leadership } \\
\text { style and } \\
\text { employee } \\
\text { commitment } \\
\text { at a } \\
\text { parastatal } \\
\text { company in } \\
\text { South } \\
\text { Africa. }\end{array}$ & $\begin{array}{l}\text { Inter- } \\
\text { national } \\
\text { Economics } \\
\text { and Business } \\
\text { Research } \\
\text { Journal }\end{array}$ & $\begin{array}{l}\text { Tshwane } \\
\text { University } \\
\text { of } \\
\text { Techno- } \\
\text { logy } \\
\text { Business } \\
\text { School } \\
\text { (RSA) }\end{array}$ & Quant. \\
\hline 7 & $\begin{array}{l}\text { Mokgolo, } \\
\text { M.M., P. } \\
\text { Mokgolo } \\
\text { \& M. } \\
\text { Modiba }\end{array}$ & 2012 & $\begin{array}{l}\text { Transform- } \\
\text { ational } \\
\text { leadership } \\
\text { in the South } \\
\text { African } \\
\text { public } \\
\text { service after } \\
\text { the April } \\
2009 \\
\text { national } \\
\text { elections. }\end{array}$ & $\begin{array}{l}\text { SA Journal } \\
\text { of Human } \\
\text { Resource } \\
\text { Manag- } \\
\text { ement }\end{array}$ & $\begin{array}{l}\text { University } \\
\text { of South } \\
\text { Africa } \\
\text { (RSA) }\end{array}$ & Quant. \\
\hline
\end{tabular}




\begin{tabular}{|c|c|c|c|c|c|c|}
\hline 8 & $\begin{array}{l}\text { Ngcobo, } \\
\text { T.M. }\end{array}$ & 2010 & $\begin{array}{l}\text { Organic } \\
\text { leadership } \\
\text { associated } \\
\text { with } \\
\text { associated } \\
\text { with good } \\
\text { academic } \\
\text { perform- } \\
\text { ance: an } \\
\text { ethno- } \\
\text { graphic } \\
\text { study of two } \\
\text { South } \\
\text { African } \\
\text { secondary } \\
\text { schools }\end{array}$ & $\begin{array}{l}\text { Inter-national } \\
\text { Studies in } \\
\text { Educational } \\
\text { Admini- } \\
\text { stration }\end{array}$ & $\begin{array}{l}\text { University } \\
\text { of the } \\
\text { Western } \\
\text { Cape } \\
\text { (RSA) }\end{array}$ & \\
\hline 9 & $\begin{array}{l}\text { Nkomo, } \\
\text { S. \& D. } \\
\text { Kriek }\end{array}$ & 2011 & $\begin{array}{l}\text { Leading } \\
\text { change in } \\
\text { the 'new' } \\
\text { South } \\
\text { Africa. }\end{array}$ & $\begin{array}{l}\text { Journal of } \\
\text { Occupational } \\
\text { and Organi- } \\
\text { zational } \\
\text { Psychology }\end{array}$ & $\begin{array}{l}\text { University } \\
\text { of Pretoria } \\
\text { (RSA); } \\
\text { University } \\
\text { of the } \\
\text { Witwaters- } \\
\text { rand } \\
\text { Business } \\
\text { School } \\
\text { (RSA) }\end{array}$ & Qual. \\
\hline 10 & $\begin{array}{l}\text { Scott, S. } \\
\& \text { J.F.A } \\
\text { Rarieya }\end{array}$ & 2011 & $\begin{array}{l}\text { Professional } \\
\text { development } \\
\text { of school } \\
\text { leaders: } \\
\text { cross- } \\
\text { cultural } \\
\text { comparisons } \\
\text { from } \\
\text { Canada and } \\
\text { East Africa. }\end{array}$ & ISEA & $\begin{array}{l}\text { University } \\
\text { of Calgary } \\
\text { (Canada); } \\
\text { Aga Khan } \\
\text { University } \\
\text { (Tanzania) }\end{array}$ & Mixed \\
\hline
\end{tabular}




\begin{tabular}{|c|c|c|c|c|c|c|}
\hline 11 & Thom, D. & 2014 & $\begin{array}{l}\text { Business } \\
\text { leadership } \\
\text { and } \\
\text { continuing } \\
\text { professional } \\
\text { development } \\
\text { of Education } \\
\text { management } \\
\text { teams in a } \\
\text { South } \\
\text { African } \\
\text { school } \\
\text { group. }\end{array}$ & ISEA & $\begin{array}{l}\text { University } \\
\text { of South } \\
\text { Africa } \\
\text { (RSA) }\end{array}$ & Qual. \\
\hline 12 & $\begin{array}{l}\text { Wakahiu, } \\
\text { J. }\end{array}$ & 2013 & $\begin{array}{l}\text { Making a } \\
\text { difference: } \\
\text { the role of } \\
\text { religious } \\
\text { women in } \\
\text { bringing } \\
\text { democratic } \\
\text { leadership } \\
\text { into Africa. }\end{array}$ & $\begin{array}{l}\text { Journal of } \\
\text { Leadership, } \\
\text { Account- } \\
\text { ability and } \\
\text { Ethics }\end{array}$ & $\begin{array}{l}\text { Marywood } \\
\text { University } \\
\text { (USA) }\end{array}$ & Qual. \\
\hline 13 & $\begin{array}{l}\text { Ward, } \\
\text { J.A. \& S. } \\
\text { Kiruswa }\end{array}$ & 2013 & $\begin{array}{l}\text { Rise to } \\
\text { Leadership: } \\
\text { an } \\
\text { evaluation } \\
\text { of African } \\
\text { Maasai } \\
\text { Women's } \\
\text { leadership. }\end{array}$ & $\begin{array}{l}\text { Journal of } \\
\text { Inter-national } \\
\text { Business } \\
\text { Research }\end{array}$ & $\begin{array}{l}\text { Regent } \\
\text { University } \\
\text { (RSA) }\end{array}$ & Quant. \\
\hline
\end{tabular}

Table 1: Empirical articles that investigated leadership in Africa over the past seven years

Of the thirteen articles documented; five were conducted within the business discipline, four in the education sector, three in the public 
administration field, and one in the spiritual discipline. Interesting to note is that only six of the articles produced were by authors from academic institutions in Africa, specifically South Africa, while seven of the articles were written by authors affiliated with universities in the United States of America.

The thirteen articles that were selected and documented - presented in Table 1 above - were then studied several times for information relevant to the body of knowledge as described by De Vos et al. (2011:509-513). The section does not provide a statistical view of the findings (that is a meta-analysis), but it rather provides a summary and critique of the findings, typical of a systematic literature review.

In the next section, the findings are reported using a qualitative style. Only constructs that are explicitly stated are reported in the different categories. No effort was made to assume anything that was not explicitly reported in the articles, as this would have introduced bias.

\section{Findings Relating To Concepts}

Concepts provide an overarching view of what the article is addressing and they were identified as the keywords that appear in the article's abstract. Of the thirteen articles listed in Table 1, eight did not have keywords listed. The other six articles had the keyword 'leadership' mentioned three times and the concept 'Africa/African' were listed twice. No other word was listed more than twice.

\section{Findings Pertaining to Statements (Definitions, Hypothesis, Propositions, and Truth Statements)}

As mentioned previously, definitions are statements by which social phenomena are understood and they provide meaning to a construct. When searching for definitions in the thirteen articles it was only sentences that included the words 'definition', 'described as', 'defining' and 'viewed as', that were considered as statements defining the concept of leadership. Only two statements were identified as definitions of leadership and the two definitions are as follows: 'Leadership is defined as an influence relationship among leaders and followers who collectively intend real changes that affect their shared purpose' (Banatu-Gomez \& Rohrer 2011:161) 'Leadership is viewed as 
being mainly about an individual's ability to influence the attitudes and activities of others' (Ngcobo 2010:21).

Although all of the above definitions describing leadership varied, the constant concept used to describe leadership is influence, with the others being collective and communal.

Certain articles explicitly related statements of expected outcomes (either hypotheses or propositions) which were intended to be tested through the research process. The hypotheses statements in the respective articles were as follows:

- Mokgolo, Mokgolo, and Modiba (2012:3-4) formulated three hypothetical statements maintaining that transformational leadership has a beneficial relationship with subordinate leadership acceptance, job performance and job satisfaction.

- Bush and Glover's (2013:21) hypothesis is that distributed leadership results in effective management (of schools).

- Ward and Kiruswa (2013:113) formulated two hypothetical statements stating that having a formal education and a mentor contribute positively to the attainment of leadership positions, while arranged marriages and increased roles have a negative impact on the achievement of leadership positions (for Maasai women).

- Garg and Ramjee (2013:1416) formulated nine hypotheses around the relationship between various leadership styles practiced in organizations (transactional, transformational, and laissez-faire) and their influence on employee commitment (normative, affective, and continuance). They indicate that leadership style plays an important role in determining levels of affective commitment, continuance commitment and normative commitment.

- Chatbury, Beaty and Kriek's (2011:57) hypothesis is that there is a relationship between servant leadership and interpersonal trust.

- El Ansari (2012:174) states that leadership relates to a sense of ownership and the member's commitment.

While the hypotheses above are from studies conducted on leadership in Africa, they do not predominantly focus on elements particular to Africa. Statements that state the relationship between constructs were described in the 
preceding paragraphs. The following propositions were identified in the articles: Bolden and Kirk (2009:83) suggest that given that Africa has a broad spectrum of cultural, religious and ethnic diversity, the term African leadership may be too broad to define exactly what it is. They propose, however, that there is a relationship between leadership, context, and cultural factors in Africa. Thom (2014:32) suggests that business leadership competencies could improve the quality of managerial leadership (in schools). Ngcobo's (2010:31) proposition is that leadership (at African township schools) forms a basis of a culture that fosters and supports good (academic) performance. Compared to the hypotheses, these propositions seem to have more of a focus on Africa.

As statements formulated from testable claims the following truth statements were articulated in the respective quantitative articles:

- Mokgolo, Mokgolo and Modiba (2012:1) found that transformational leadership has a positive correlation with subordinate leadership acceptance, performance and job satisfaction.

- Bush and Glover (2013:39) report that in the South African school context, the concept of distributed leadership is used in different ways and to varying extent. As a result, it is impossible to present a blueprint for effectively distributed leadership. The hypothesis that distributed leadership results in successful management of schools and could therefore not be confirmed and generalized.

- Ward and Kiruswa (2013:118) found no relationship between education and a rise to leadership, while a positive correlation exists between having a mentor and a rise to leadership. The strongest predictor of attaining a leadership position was arranged marriages and roles outside work.

- Garg and Ramjee (2013:1411) report that there is a relationship between transformational leadership behaviours with affective, continuance and normative commitment. Transactional leadership was found to have a positive relationship with normative commitment, while laissez-faire leadership has a negative relationship with affective, normative and continuance commitment.

- Chatbury et al. (2011:60) report that there is a relationship between servant leadership and interpersonal trust between low level workers and their managers. The authors emphasize that these findings should 
not be generalized in more complex populations who might require different business models.

- El Ansari (2012:183) reports that leadership skills (collaboration, coalition, and facilitative styles) are critical for the processes and outcomes of inter-professional partnership and sense of ownership.

- In many respects these findings don't report on anything particular in Africa, apart from applying Eurocentric principles in the African context.

- From the qualitative studies, the following statements of truth were made: Bolden and Kirk (2009:80) state that African leadership holds multiple and sometimes conflicting meanings and connotations. Africans aspire to leadership founded on humanistic principles; a more inclusive and participative leadership that values individual differences, authenticity and serving others. They conclude that leadership in Africa bears similarities to those of other regions, but cultural and contextual factors have a role to play in its construction and enactment. Thom (2014:37) found that there are distinct business leadership competencies that are lacking in education management and that need to be developed in order to improve managerial leadership in schools.

- Ngcobo (2010:25) reports that school cultures that foster communal ownership on issues of importance to the community lead to good academic performance among South African schools. He also states that the type of leadership linked to good academic performance is one which emerges organically from within an organisation - in this instance, schools.

The qualitative studies address the African context clearer than the preceding quantitative studies.

\section{Findings Pertaining to Conceptual Frameworks}

The findings on conceptual frameworks (typologies, models, theories, and paradigms) are shared in the next paragraphs.

The types of leadership (with reference to typologies) that were presented in the articles included value-based and charismatic leadership, distributed leadership, servant leadership, collaborative involvement, 
motivational influence, inspirational leadership, leadership with intellectual stimulation, shared leadership, leadership that inspires a shared vision, splittask dual leadership, and transformational and transactional leadership (Garg \& Ramjee 2013:1411-1435; Mokgolo, Mokgolo \& Modiba 2012:1-9; Ngcobo 2010:19-34; Nkomo \& Kriek 2011:453-470; and Wakahiu 2013:78-95). None of these has a uniquely African flavour.

The theoretical models presented below describe relationships suggested in the articles that were reviewed.

\section{Leadership Style Influences Attitude and Organizational Performance}

Some of the articles share a view that certain leadership practices or behaviours have a direct impact on organizational performance, growth, or change in behaviour. For example, Banatu-Gomez and Rohrer (2011:161) investigated the influence of leadership practice on 'inspiring a shared vision' in a financial institution. In particular, their model argues that the leadership practice of inspiring a shared vision will influence organizational growth. Similarly, El Ansari (2012:175) explored the importance of communication, collaboration, involvement of others, and providing a social/educational capacity as critical for partnership leadership. Nkomo and Kriek (2011:460) investigated how leaders effectively direct change in the new South Africa. Using the typology of visionary leadership, they argued that leading change by providing or inspiring a shared vision and values result in effective leadership. Mokgolo, Mokgolo and Modiba (2012:2) investigated transformational leadership in South Africa following the 2009 elections. They argued that transformational leadership is vital to effective organizational success. Leadership behaviour attributes associated with transformational leadership, such as influence, intellectual stimulation and inspiration were found to be beneficial to organizational success.

\section{Leadership Style Influences Behaviour}

The following were which suggest that influences behaviour:

- Garg and Ramjee (2013:1414) investigated the relationship between leadership and employee behaviour in relation to their level of 
commitment. The theoretical model used in their investigation is that both transactional and transformational leadership styles play a role in employee commitment. They further report that the two stated leadership practices will further enhance organizational effectiveness.

- Similarly, Banatu-Gomez and Rohrer (2011:161) point out that specific leadership practices can nurture behaviour that fosters accountability, innovation, and sustainable change, leading to increased organizational performance.

- In another empirical research article, Chatburry, Beaty and Kriek (2011:60) report that servant leadership at the bottom of the pyramid engenders trust relationships essential for cooperation, teamwork, and collaboration between stakeholders.

\section{Leadership Effectiveness is a Result of Shared Ownership of Responsibilities}

Some articles pose a view that a context that allows for shared distribution of leadership responsibilities creates opportunities for leadership effectiveness. For example, Bush and Glover (2013:21-22) suggest that distributed leadership increases organizational success. Their model argues that distributed leadership ensures the collective use of talents in order to deliver successfully on leadership activities (Bush \& Glover 2013:29). Distributed leadership recognizes that influence and leadership is not necessarily positional and that where decision making is distributed or shared across the organization, the results thereof are success and effectiveness (Bush \& Glover 2013:22-32). Likewise, Bush and Glover (2013:22), using the typology of distributed leadership, argued that it has an impact on team development. Wakahiu (2013:81) argues that democratic and collaborative leadership result in collective action and ownership, while El Ansari (2012:183) argues that dispersed leadership is related to team efficacy, satisfaction, and outcomes. Ngcobo (2010:25) also suggests that leadership behaviour fostering communal or shared leadership promotes inclusiveness.

\section{Findings Pertaining to Research Paradigms}

The researchers did not explicitly state the research paradigms in the thirteen articles reviewed. Taking into account the argument in the description in 
section 5, in this current research, the methodologies and data collection in the thirteen articles were used to infer the research paradigms that informed the various studies. The articles were classified into any of the three major research paradigms; positivist or post-positivist, interpretivist, and critical.

- Positivist or post-positivist paradigms are mostly associated with quantitative research methodologies, founded on the belief that there is an objective reality out there that can be studied through prediction and control. This paradigm argues for cause and effect in relationships and finding an objective truth by asking questions and hypothesizing upfront (Shah \& Al-Bargi 2013:254-256). The methods of collecting data used by positivist researchers include questionnaires, closedended questions, and structured interviews. Emphasis is placed on sampling, validity, and reliability of the research findings. By reviewing the thirteen articles, six of the articles could be classified within the positivist paradigm. These studies used quantitative methodology, employed surveys as the primary research method, and relied on statistical, correlational and descriptive analyses to understand the data. The six articles that are categorized as fitting the positivist paradigms were: Bush and Glover (2013:21-40), Chatburry, Beaty and Kriek (2011:57-61), Garg and Ramjee (2013:1411-1435), Mokgolo, Mokgolo and Modiba (2012:1-9), Thom (2014:28-39) as well as Ward and Kiruswa (2013:109-120).

- Interpretative paradigm emerged as a criticism to positivism and their primary argument is that reality is relative and as a result there are multiple realities of phenomena. This paradigm is associated with terms such as constructionism, naturalism, qualitative research, grounded theory and ethnography (Kirkwood \& Campbell-Hunt 2007:223). For interpretative researchers, the aim is not to generalize but to generate a few constructions through which there is consensus after interpreting different and subjective understanding or meaning applied to a social phenomenon (Shah \& Al-Bargi 2013: 254-256, Wayhuni 2012:71). The methods of collecting data include case studies, interviews, field notes, and diary observations. By reviewing the thirteen articles, four of the articles could be classified within the interpretative paradigm as these articles used qualitative research as a 
primary methodology. Data was collected using unstructured observations, questionnaires, semi-structured interviews, informal conversations, case studies, and life stories, among others. Comparative, content and thematic analyses were used to understand data by most of these researchers. The four articles that are categorized as fitting the interpretative paradigm were those of Banatu-Gomez and Rohrer (2011:156-167), Ngcobo (2010:19-34), Nkomo and Kriek (2011:453-470) and Wakahiu (2013:78-95).

- The critical paradigm is aimed at searching for change and improving the lives of the participant. It challenges conventional ways of conducting research by arguing that reality is shaped by social, cultural, political, and ethnic values (Shah \& Al-Bargi 2013:254-256). The methodology used is dialogue aimed at facilitating transformation of the phenomenon in question. Mixed methods are the preferred method used in the critical paradigm, as they are found to be allowing both qualitative dialogue as well as the collection of appropriate data using quantitative methods (Wayhuni 2012:70). It is also argued that the researchers using this paradigm can apply quantitative, qualitative or mixed methods to design their research (Shah \& Al-Bargi 2013:254256). One article (Bolden \& Kirk 2009:69-86) clearly used a critical paradigm.

Two articles (El Ansari 2012:174-184; Scott \& Rarieya 2011:65-81) used mixed methods, which could have been informed by a positivist, interpretative or critical paradigm. While there is a representation of the different paradigms on the various articles, it is clear that the positivist or postpositivist paradigm remains dominant in research. In light of the observation that African nationalism and philosophy are critical in nature, it is interesting that there is limited research that uses the critical paradigm to understand leadership in the African context.

\section{Conclusions}

This article reviewed empirical research literature on the practice of leadership in the African context. The primary aim of the literature review was to reflect the extent of the body of knowledge in the field of leadership in Africa and to 
identify the gaps and well-researched areas. As presented in the preceding sections, it is apparent that while there is a plethora of articles on leadership in Africa across multiple disciplines, there is a paucity of empirical data on the subject. The fact that after a thorough systematic literature review, only thirteen studies reporting empirical data could be retrieved, is evidence of the scarcity of scientific research on leadership in the African context.

With regard to concepts, most of the articles did not list concepts in their keywords section and this suggests that searching for African leadership using the keywords selected could have limited the number of empirical articles conducted on leadership in Africa. It is, in fact, a concern that so few researchers took care to state keywords, which would have made it easier to locate articles.

The results pertaining to statements were presented in four headings, namely definitions, hypotheses, propositions, and truth statements. With regards to definitions, it was found that while most articles do not define leadership in Africa, the two definitions reported did not provide any new (African) meaning to the concept of leadership. For example, the concept used to describe leadership, i.e. influence, is not unique to Africa. It is only in the Bolden and Kirk (2009:69-86) qualitative study on African leadership where there is a suggestion outlined that within the African context, cultural factors have an impact on how leadership is constructed. To this end, they report that Africans aspire to a leadership based on humanity, a leadership that is inclusive, and one that values individual differences with a need for serving those whom one is entrusted to lead.

The observations from the articles with regards to hypotheses show that the formulated hypotheses were not necessarily unique and particular to Africa. In three studies, however, propositions focusing specifically on the African context were formulated. It also seemed that the quantitative studies used traditional Western instruments. Only the qualitative studies that do not follow the more rigid empiricist model, included uniquely African themes.

All articles articulated findings viz; truth statements. In line with the hypotheses and propositions, it is found that none of the truth statements are unique to Africa, except for that formulated by Bolden and Kirk (2009:80). This is also to be expected as the hypotheses never included any elements particular to Africa. If anything, the truth statements which followed from the hypotheses affirmed that Western variables acted in a very predictable manner in the African context. 
The conceptual frameworks (typologies, models, theories, and paradigms) used in the different studies are not necessarily unique to Africa. Considering typologies, the example types of leadership presented, such as charismatic, distributed, inspirational, and servant leadership, are types of leadership that is reported in global research articles. It is for this reason that one cannot argue that researchers acknowledge leadership practices unique to Africa.

The theories and models used in the aforementioned studies are typically Western, and are simply applied to the African context. Furthermore, the models inferred in the published articles are very simple in nature, for example, leadership results in this or that with no context or at least no African variable listed.

As observed from the research paradigms, there is only one research study conducted that critically explored the phenomenon of leadership in the African context. Most of the other articles followed the conventional paradigms and as a result, we do not observe much difference in the findings around leadership relative to the rest of the world. Given that the African context is diverse, it might be beneficial for critical theorists to explore the concept of leadership in Africa.

The findings of this research simplify concurrence with Chatbury, Beaty and Kriek (2011:58) who stated that in general, empirical literature on leadership is mostly conducted by Western researchers. Similarly, Bolden and Kirk (2009:71) argue that existing empirical data on leadership in Africa is by Western academics who are seemingly motivated by their desire to provide Western managers with an understanding of how to do business in Africa as opposed to assisting Africans to appreciate, develop, or enhance their own approaches. To this end, the extent to which the conclusions by the majority of these articles were presented through the Western epistemological lens remains an interesting question, which should be investigated.

The final conclusion that can be drawn from this study is that the body of knowledge on leadership is inadequately developed and needs to receive serious attention if it is to be recognized in the world of science. Ideas on what could be done in this regard are presented in the recommendations section that follows.

\section{Recommendations}

There are multiple implications from the findings of this systematic literature 
review. At the onset, there is a need to have more empirical research conducted in the African context. Moreover, African institutes should lead research around topics particular to the African context. For example, as identified through research, leadership in Africa or African leadership has sparked interest in the last few years and it would have been good to find empirical research spearheaded by institutions in Africa as opposed to what transpired through the current literature findings. The limited number of the discovered empirical work suggests that there is a need to investigate leadership within the African context, and there is a need for more academics in Africa to investigate leadership so that they can expand knowledge and demystify the construct of 'African leadership'. Organizations such as the Thabo Mbeki African Leadership Institute (TMALI), the African Leadership Institute (AFLI) and the African Leadership Institute, USA, among others, should be called upon to support the concept of African leadership and to fund research endeavours in this subject.

The surprising finding was the lack of operational definitions on African leadership. Though philosophers have debated the matter at length, very little has been done in the world of science. An important step towards establishing a body of knowledge on this topic would be to operationally define the meaning of leadership in Africa. In doing so, future researchers will be able to determine whether leadership in Africa is any different from leadership in other parts of the world. Thorough debate on this matter is encouraged.

Most striking about the investigation was the lack of anything particular to Africa in hypotheses, models, theories, and paradigms. Researchers seem to replicate Eurocentric research within Africa, without adding the context as a variable, and without adjusting their methodologies and paradigms to the local context. In going forward, it might be worthwhile for researchers to critically assess different research paradigms applied and to move away from conventional paradigms and methodologies.

Researchers are encouraged to make use of the practice of listing keywords, as this will assist other researchers or keen readers of the topics to easily identify concepts that are being investigated.

\section{References}

Avolio, B., F. Walumbwa \& T. Weber 2009. Leadership: Current Theories, 
Research and Future Directions. Annual Review of Psychology 60: 421449.

Babbie, E.R \& J. Mouton 2001. The Practice of Social Research. $1^{\text {st }}$ Edition. Cape Town: Oxford University Press.

Banatu-Gomez, M. \& W.G. Rohrer 2011. The Influence of the Leadership Practice 'Inspiring a shared vision'. On Group Norms in an Organisational

Culture of Financial Institutions in the Gambia, West Africa. Journal of American Academy of Business 17,1: 156-167.

Bolden, R. \& P. Kirk 2005. Leadership in Africa: Meanings, Impact and Identities. Paper presented at the Fourth international conference on leadership research. Available at http://www.bc-interaction.org (Accessed on 26 July 2014.)

Bolden, R. \& P. Kirk 2009. African Leadership: Surfacing New Understandings through Leadership Development. International Journal of Cross-cultural Management 9,1: 69-86.

Bush, T. \& D. Glover 2013. School Management Teams in South Africa: A Survey of School Leaders in Mpumalanga Province. International Studies in Education Administration 41,1: 21-40.

Chatbury, A., D. Beaty \& H. Kriek S 2011. Servant Leadership, Trust and Implications for the 'base-of-the-pyramid' Segment in South Africa. South African Journal of Business Management 42,4: 57-61.

Creswell, J. 1998. Qualitative Inquiry and Research Design: Choosing among Five Traditions. New York: Sage Publication.

Denyer, D. \& D. Tranfield 2009. Producing a Systematic Review: The Sage Handbook of Organisational Research Methods. New York: Sage Publication.

De Vos, A.S., H. Strydom, C.B. Fouché \& C.S.L. Delport 2011. Research at Grassroots: For the Social Sciences and Human Services Professions. $4^{\text {th }}$ Edition. Pretoria: Van Schaik.

Dinh, J.E., R.G. Lord, W.L. Gardner, J.D. Meusser, R.C. Liden \& J. Hu 2014. Leadership Theory and Research in the New Millennium: Current Theoretical Trends and Changing Perspectives. The Leadership Quarterly 25,1: 36-62.

El Ansari, W. 2012. Leadership in Community Partnership: South African Study and Experience. European Journal of Public Health 20,3: 174184.

Garg, A.K. \& D. Ramjee 2013. The Relationship between Leadership Styles 
and Employee Commitment at a Parastatal Company in South Africa. International Business and Economics Research Journal 12,11: 14111435.

Gay, L. \& P. Airasian 2003. Educational Research: Competencies for Analysis and Application. $7^{\text {th }}$ Edition. New Jersey: Upper Saddle River.

Green, J.C.D. \& A. Adams 2006. Writing Narrative Literature Reviews for Peer-reviewed Journals: Secrets of the Trade. Journal of Chiropractic Medicine 53: 102-117.

Grint, K. 2005. Problems, Problems, Problems: The Social Construction of Leadership. Human Relations 58,11: 1467-1494.

Haruna, P. 2009. Revising Leadership Paradigm in sub-Saharan Africa: A Study of Community-based Leadership. Public Administration Review 941-950.

Humphreys, J., D. Zhao, K. Ingram, J. Gladstone \& L. Basham 2010. Situational Narcissism and Charismatic Leadership: A Conceptual Framework. Institute of Behavioural and Applied Management 11,2: 118134.

Jones, S., G. Lefoe, M. Harvey \& K. Ryland 2012. Distributed Leadership: A Collaborative Framework for Academics, Executives and Professionals in Higher Education. Journal of Higher Education Policy and Management 34,1: 67-78.

Kable, P.J. \& S. Maslin-Prothero 2012. A Structured Approach to Documenting a Search Strategy for Publication: A 12 Step Guidelines for Authors. Nurse Education Today 32: 878-886.

Kirkwood, J. \& C. Campbell 2007. Using Multiple Paradigm Research Methodologies to Gain New Insights into Entrepreneurial Motivations. Journal of Enterprising Culture 15,3:219-241.

Kuada, J. 2010. Culture and Leadership in Africa: A Conceptual Model and Research Agenda. Africa Journal of Economic and Management Studies 1,1: 9-24.

Littrell, R.F. \& S.M. Nkomo 2005. Gender and Race Differences in Leader Behaviour Preferences in South Africa. Women in Management Review 20,8: 562-580.

Marturano, A. \& J.G. 2008. Leadership: The Key Concepts. New York: Routledge.

Mbigi, L. 2000. In Search of the African Business Renaissance. Randburg: Knowledge Resources. 
Mboup, S.B. 2008. Conflicting Leadership Paradigms in Africa: A Need for an African Renaissance Perspective. International Journal of African Renaissance Studies 3,1: 94-112.

Mokgolo, M.M., P. Mokgolo \& M. Modiba 2012. Transformational Leadership in the South African Public Service after the April 2009 National Elections. SA Journal of Human Resource Management 10,1: \#334. Available at: http://dx.doi.org/10.4102/sajhrm.v10i1.334. (Accessed 01 March 2015.)

Muchiri, M.K. 2011. Leadership in Context: A Review and Research Agenda for sub-Saharan Africa. Journal of Occupational and Organisational Psychology 84: 440-452.

Ngcobo, T. 2010. Organic Leadership Associated with Good Academic

Performance: An Ethnographic Study of Two South African Township

Secondary Schools. International Studies in Education Administration 38,3: 19-34.

Nightingale, A. 2009. A Guide to Systematic Literature Review. Surgery 27,9: 381-384.

Nkomo, S.M. \& D. Kriek 2011. Leading Organizational Change in the 'New' South Africa. Journal of Occupational and Organisational Psychology 84,3: 453-470.

Posner, B.Z. 2013. 'It's how leaders behave that matters, not where they are from'. Leadership \& Organisational Development Journal 34,6: 573-587. Robson, C. 2011. Real World Research: A Resource for Users of Social Research Methods in Applied Settings. $3^{\text {rd }}$ Edition. Oxford: John Wiley \& Sons.

Robson, L.S, J.A. Clark, K. Cullen, A. Bielecky, C. Severin, P.L. Bigelow \& Q. Mahood 2007. The Effectiveness of Occupational Health and Safety Management Systems Interventions: A Systematic Review. Safety Science 45,3: 329-353. Available at: http://dx.doi.org/j.ssci.2006.07.003 (Accessed 05 March 2015).

Shah, S.R. \& A. Al-Bargi 2013. Research Paradigms: Researchers' Worldviews, Theoretical Frameworks and Study Design. Arab World English Journal 4,4: 252-262.

Scott, S. \& J.F.A. Rarieya 2011. Professional Development of School Leaders: Cross-cultural Comparison from Canada and East Africa. International Studies in Education Administration 38,1: 65-81.

Thom, D. 2014. Business Leadership Continuing Professional Development of 
Education Management Teams in a South African School Group. International Studies in Education Administration 42,1: 28-39.

Tranfield, D., D. Denyer \& P. Smart 2003. Towards a Methodology for Developing Evidence-informed Management Knowledge by Means of Systematic Review. British Journal of Management 14,2: 207-222.

Van der Colff, L. 2003. Leadership Lessons from the African Tree. Management Decisions 41,3: 257-261.

Wakahiu, J. 2013. Making a Difference: The Role of Women's Religions in Bridging Democratic Leadership in Africa. Journal of Leadership, Accountability and Ethics 10,5: 78-95.

Walumbwa, F.O., B.J. Avolio \& S. Aryee 2011. Leadership and Management in Africa: A Synthesis and Suggestion for Future Research. Journal of Occupational and Organisational Psychology 84: 425-439.

Ward, J.A. \& S. Kiruswa 2013. Rise to Leadership: An Evaluation of African Maasai Women's leadership. Journal of International Business Research 12,2: $109-120$.

Wahyuni, D. 2012. The Research Design Maize: Understanding Paradigms, Cases, Methods and Methodologies. Journal of Applied Management Accounting Research 10,1: 69-80.

White, A. \& K. Schmidt 2005. Systematic Literature Reviews. Contemporary Therapies in Medicine 13: 54-60.

Matete Lerutla Graduate School of Business Leadership University of South Africa South Africa Matete09md@gmail.com

Renier Steyn Graduate School of Business Leadership University of South Africa

South Africa steynr@unisa.ac.za 